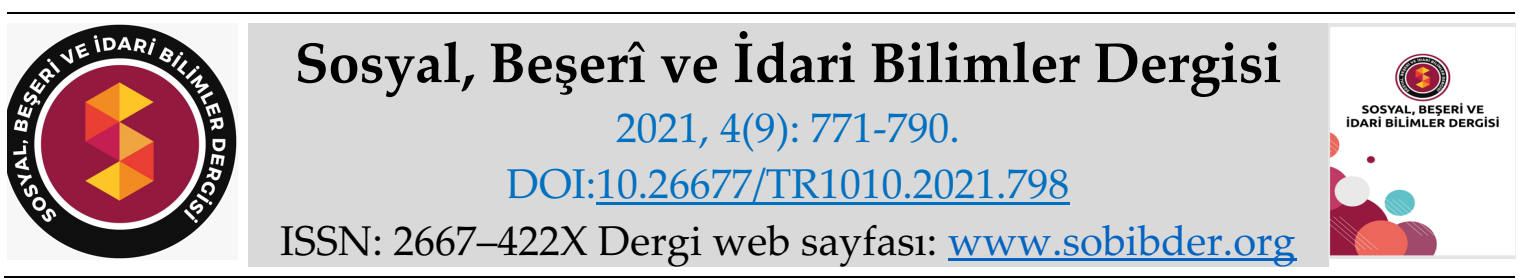

ARASTTIRMA MAKALESI

\title{
Turizm Bağlamında Çocukların Tatil Algılarına İlişkin Çağrışımların Resimsel Analizi*
}

Dr. Öğr. Üyesi Makbule CiVELEK, Zonguldak Bülent Ecevit Üniversitesi, Karadeniz Ereğli Turizm Fakültesi, Zonguldak, e-posta: makbule.civelek@beun.edu.tr ORCID: https://orcid.org/0000-0002-3997-6508

Arş. Gör. Perihan CIVELEK, Bilecik Şeyh Edebali Üniversitesi, Sağlık Bilimleri Fakültesi, Bilecik, e-posta: perihan.civelek@bilecik.edu.tr

ORCID: https://orcid.org/0000-0002-2652-9282

$\ddot{O} z$

Günümüzde tatil kararlarını alma süreçlerinde çocukların aileleri üzerinde etkili olduğu bilinmektedir. Bu bağlamda çalışmanın temel amacı turizm kavramından hareketle çocukların tatile bakış açısının değerlendirilmesidir. Bu amaç doğrultusunda beş yaş grubu 23 çocuktan turizm kavramı hakkında resimler çizmesi istenmiştir. Ayrıca çocukların resimlerinden elde edilen verileri desteklemek amacıyla tatil algılarına ilişkin görüşmeler yapılmıştır. Çocuklar tarafından yapılan resimler nitel yöntem aracıllğ̆ıla görsel analize ve içerik analizine tabi tutulmuştur. Çalışma sonuçlarına göre tatil çocuklara en çok güneş, deniz, ağaç, kuş ve balık çağrışımları yapmaktadır. Resimde kullanılan renkler temasında en çok mavi rengi kullanıldığı belirlenmiştir. Resim özellikleri temasından elde edilen sonuçlara bakıldığında çocukların resimlerinde en çok düzleme özelliği saptanmıştır. Çocukların tatil algılarına ilişkin görüşme sonuçlarına göre ise önceden yaşadıkları tatil deneyimlerini aktardıkları tespit edilmiştir. Çocukların tatil algılarına yönelik çizimleri ile görüşmelerden elde edilen ifadeler arasında bir tutarlılık olduğu sonucunu varılmıştır.

* Bu çalışmanın özet bildirisi “5. Uluslararası Avrasya Sosyal Bilimler Kongresi'nde sunulmuştur.

Anahtar Kelimeler: Turizm Algısı, Tatil Çağrışımları, Çocuk Resimleri.

Makale Gönderme Tarihi: 09.05.2021

Makale Kabul Tarihi: 01.09.2021

\section{Önerilen Atıf:}

Civelek, M. ve Civelek, P. (2021). Turizm Bağlamında Çocukların Tatil Algılarına İlişkin Çağrışımların Resimsel Analizi, Sosyal, Beşeri ve İdari Bilimler Dergisi, 4(9): 771-790.

(c) 2021 Sosyal, Beşerî ve İdari Bilimler Dergisi. 


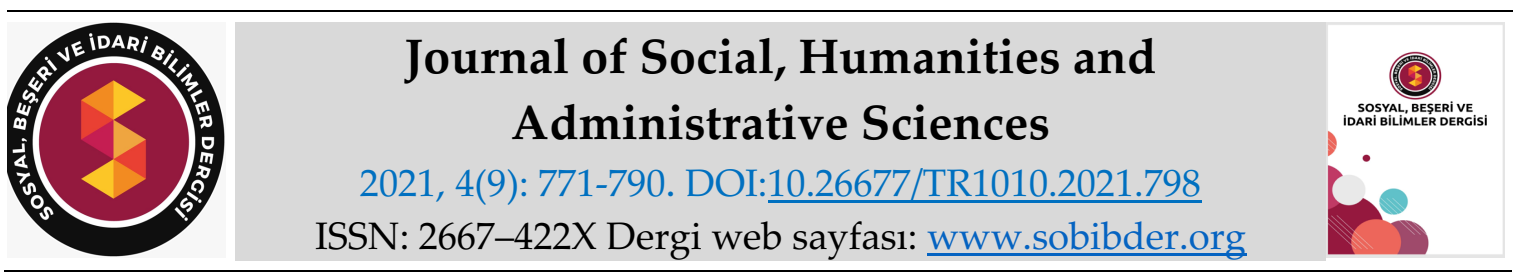

RESEARCH PAPER

\title{
Drawing Analysis of Connotations Regarding Children's Holiday Perceptions in The Context of Tourism
}

Assistant Prof. Dr. Makbule CIVELEK, Zonguldak Bülent Ecevit University, Karadeniz Ereğli

Faculty of Tourism, Zonguldak, e-mail: makbule.civelek@beun.edu.tr

ORCID: https://orcid.org/0000-0002-3997-6508

Research Assistant Perihan CIVELEK, Bilecik Şeyh Edebali University, Faculty of Health Sciences, Bilecik, e-mail: perihan.civelek@bilecik.edu.tr

ORCID: https://orcid.org/0000-0002-2652-9282

\begin{abstract}
The aim of the study is to determine children's perceptions of holiday with their drawing. The study group of the research consists of 23 children in the five-age group. The children were asked to draw a picture regarding their perceptions of holiday. Also, interviews were conducted with children in order to examine children's perceptions of holiday. The drawings were examined through visual and content analysis. It is seen that the holiday mostly evokes sun, sea, tree, bird and fish connotations for children. It was determined that children mostly used blue in their drawings. It was found that the most flattening feature was seen in the children's drawings. When the opinions of children regarding their perceptions of holiday are examined, it is seen that the perceptions of holiday are mostly related to the holiday experiences of the children. There is a consistency between the children's drawings and the expressions obtained from the interviews.
\end{abstract}

Keywords: Perception of Tourism, Connotations of Holiday, Children's Drawings.

Received: 09.05.2021

Accepted: 01.09.2021

\section{Suggested Citation:}

Civelek, M. and Civelek, P. (2021). Drawing Analysis of Connotations Regarding Children's Holiday Perceptions in The Context of Tourism, Journal of Social, Humanities and Administrative Sciences, 4(9): 771-790.

(C) 2021 Sosyal, Beşerî ve İdari Bilimler Dergisi. 


\section{Gíriş}

Turizm ve tatil algısı turistlerin beklentileri ve deneyimleri nedeniyle değişiklik göstermektedir. Günümüzde gelişmiş ülkelerde turizm bir ihtiyaç iken, gelişmekte olan ülkelerde ise sosyo ekonomik değişkenlere bağlı olarak lüks bir olgu olarak görülebilmektedir. Turizmin bu değişimi üzerine çeşitli değişkenler göz önüne alınarak araştırmalar yapılmaktadır. Bu değişkenlerden biri de çocukların tatil kararı alma hususunda aileleri üzerindeki etkilerinin saptanmasına yöneliktir. Çocuklar, ailelerin en küçük yapı taşlarını oluşturmaktadır. Aileler tüketim kararlarını çocuklarının isteklerine göre şekillendirebilmektedir. Ailelerin, çocuklarının tatilde rahat edebilecekleri destinasyonları ve tesisleri tercih etmesi olasıdır. Tatil kararının alınmasında çocuklar bu nedenle etkili bir unsurdur. Tatile çıkma konusunda önemsenen çocuklar, tatille ilgili ailelerin tercihlerini de belirleyebilmektedir. Bu nedenle çocukların tatile bakış açılarını bilmek, turizme ilişkin beklentilerin de ortaya konulması açısından önem taşımaktadır.

Çocuk ve turizm konulu çeşitli araştırmalar yapılsa da araştırmalarda daha çok çocuk dostu turizm kavramı üzerinde durulduğu görülmektedir. Ulusal ve uluslararası literatürde çocukların turizm ve tatil algılarındaki çıkarımları çalışılmış olmakla birlikte sınırlı bir düzeyde kalmıştır. $\mathrm{Bu}$ kapsamda çalışmanın amacı literatürde üzerinde çalışılmamış olan beş yaş grubunun turizmden hareket edilerek tatil algılarını ortaya koymaktır. Bu amaç doğrultusunda beş yaş grubu çocuklardan tatil deneyimleri hakkında algılarını ve çağrışımlarını resmetmeleri istenmiştir.

Çocuklar kendilerini ifade edebilme aşamasında çeşitli araçları kullanmaktadır. İletişim becerilerinin geliştirilebilmesi, duygu ve düşüncelerin aktarılabilmesi ve hayal güçlerini yansıtabilmeleri amaçlarıyla resim çizmek önemli bir araç olarak kullanılmaktadır. Resim sözel olmayan iletişim kanallarından birisidir. Çocuklar için en etkili iletişim unsurlarından birini oluşturan resimler çocukların duygu, düşünceleri ve iç dünyalarına ilişkin bilgiler edinmemizi sağlamaktadır. Bebeklikten itibaren bir çizim aracı ile (kalem, pastel boya vb.) yüzey üzerinde izler bırakan çocuk aslında ilk sanatsal deneyimine çizgiler aracılığıyla başlangıç yapmış olmaktadır. Çocuklar çizimlerine hayal ettiklerini yansıtmakta ve bu nedenle çocukların çizimleri pek çok anlamı içerebilmektedir. Çocuklar için resim kendini anlatabilmenin bir aracıdır. Resimler hiçbir baskı olmaksızın çocuklara özgür bir şekilde düşüncelerini aktarma fırsatı sunmaktadır. Bu nedenle çocuğun dünyasında resim önemli bir yer tutmaktadır. Bu kapsamda çalışmada çocukların tatil algılarını en iyi resimler aracılığıyla ortaya koyabileceğinden yola çıkılarak, çocukların çizimleri ile tatil algıları incelenmiştir. Ayrıca resimlerden elde edilen bulguları desteklemek amacıyla tatil algılarına yönelik olarak çocuklarla görüşme gerçekleştirilmiştir. Çalışma soruları bu temel sorun kapsamında aşağıdaki gibi şekillendirilmiştir:

- Çocuklara tatil deyince çağrışım yapan unsurlar nelerdir?

- Çocukların turizm ve tatil kapsamında çizdikleri öğeler nelerdir?

- Çocukların resimlerinde kullandıkları renkler nelerdir?

- Çocukların tatil kapsamında çizdikleri resimler, resim özellikleri bakımından neyi ifade etmektedir?

- Çocukların daha önceki tatil deneyimlerine ilişkin görüşleri nedir?

\section{LITTERATÜR TARAMASI}

\section{Turizm Olgusu ve Çocuk}

Geçmişten günümüze değin turizm kavramının çeşitli yönlerini ortaya koyan tanımlamalar yapılmıştır. Bu tanımlamalar turizm kavramının kompleks yapısı nedeniyle farklılıklar 
göstermekle birlikte turizmin temel özeliklerinden de hareket etmektedir. Bu tanımlamaları turizmi bir sistem olarak görenler (Mill ve Morison, 1985; Gunn 1988; Leiper, 1995), turizmi kuramsal açıdan ele alanlar (Hunziker ve Krapt, 1942) turizmin sosyolojik ve psikolojik boyutlarını ön planda tutanlar (MacCannell, 1976; Pearce, 1982; McIntosh ve Gupta,1980; Dann ve Cohen, 1991), turizmin ekonomik boyutuyla ele alanlar (Çoruh, 1952; Bernecker, 1968; Archer ve Cooper, 1994) olarak sinıflandırmak mümkündür. Aynı zamanda Akoğlu'na (1971: 13) göre, 1930-1936 yılları arasında Morgenraoth, Bormann, Gölden, Norval ve Olive gibi yazarlar turizm tanımı için çıkış noktası olarak ulaştırmayı almışlar ve şahıs ulaştırması, yer değiştirme olaylarına tanımda yer vermişlerdir. Daha sonraki devrede (1938-1960) Römer, Leveille-Nizerolle, Marko ve Kolaczek gibi yazarlar ise turizm olayını her şeyden önce aile bütçesine yapılan bir tüketime bağlamakta ve turistik tüketim fonksiyonunu turizm tanıma temel olarak almaktadır. Yapılan bu sınıflandırmaya ilişkin araştırmacı görüşleri aşağıdaki gibi şekillenmektedir:

Turizmi kuramsal açıdan ele alan Hunzier ve Krapf'a (1942) göre turizm yabanciların konaklama ve seyahatlerinden doğan, sürekli olarak kalmaya ve gelir să̆layıcı bir uğraşıya dönüşmeyen ilişkilerin toplamın ifade etmektedir (Jayapalan, 2001: 11). Hunzier ve Krapt'ın bu tanımlamasına göre turizm hareketlerinin geçici konaklamadan doğması ve para kazandırma gibi bir amacının olmaması gerekliliği vurgulanmıştır. Benzer bir noktadan hareket eden Olalı ve Timur'a (1963: 179) göre turizm, insanların sürekli konutlarının bulunduğu yer dışına yaptıkları geziler ve gittikleri yerlerdeki geçici konaklamalarından doğan gereksinimlerinin karşılanmasına yönelik faaliyetlerdir. Brukart ve Medlik'in çıkış noktası da benzerlik göstermektedir. 1981 yılında yapılan bu tanıma göre ise turizm, geçici ziyaretlerden doğan, yaşanılan yer dışına mesleki nedeler dışında herhangi bir nedenle çıkılan olgu (Lickorish ve Jenkins, 1997: 3) şeklindedir.

Turizmin ekonomik yönü üzerine tartı̧maları başlatan araştırmacı 1910 yılında Avusturyalı ekonomist Hermann Von Schullar olmuştur. Yazar, turizmi başka bir ülkeden, şehir veya bölgeden yabanciların gelmesi ve geçici süre kalmalarıla ortaya çıkan hareketin ekonomik yönünü ilgilendiren faaliyetlerin tümü olarak nitelendirmektedir (Kozak vd., 2012: 1). Ekonomik yönlü başka bir tanıma göre ise turizm bir ülkeye gelen yabancların sayısını ve turizm gelirlerini artırmak, iç turizm hareketlerini geliştirmek ve yurt dışına çıkan vatandaşların seyahatlerini düzenlemekle ilgili bütün yatırım, tedbir, planlama ve uygulama faaliyetlerini kapsar (Akoğlu, 1971: 70) şeklindedir. Bernecker'e göre turizm, yabanclarn belirli bir yer, bölge veya eyalete doğru, bu yerler içinde ve bu yerlerden başka yerlere doğru seyahatleri ve orada kalmaları ile ilgili öncelikle iktisadi olayların bütünüdür (Toskay, 1983: 24). Çoruh'a (1952: 10) göre ise turizm ilk bakışta ve iktisadi manada bir mal satışıdır. Bu satış, muhtelif mahsullerin istihlak ettirilmesi ve çeşitli hizmetlerin yapılması ile olmaktadır. Turizmin ekonomik yönü üzerine yapılan tanımlarının ortak noktasında turizmin gelir getirici özelliği üzerinde durulduğu görülmektedir. Turistlerin harcamaları ile ede edilen gelir, turistik ürün ise satılan bir mal ya da hizmet olarak görülmektedir.

Turizmin sadece ekonomik bir olgu olmaması nedeniyle sosyal boyutu da göz önüne alınarak tanımlamalar yapılmıştır. Turizme sosyal boyutu ile yaklaşanlar sosyal sınıfları, alışkanlıkları ev sahibi ve misafirlerin gelenek ve göreneklerini dikkate almaktadır (Goeldner vd., 2000: 22). Turizm, insan yaşamına ilişkin bir olay olarak görülebileceği gibi insanların bir toplum içinde birlikte yaşamalarının da belirli bir yönünü oluşturan toplumsal bir olay olarak kabul edilebilir (Barutçugil, 1984: 20). Turizm, sadece ekonomik bir olay değil, sosyal, kültürel, coğrafi, siyasal yönleri olan, toplumu ve sosyal yapıyı etkisi altına alan ulusal ve uluslararası platformdaki harekettir (Ülger, 1993: 54).

Toplumun hemen hemen tüm katmanlarına sirayet ettiği düşünülen turizm olgusu, toplumun en küçük yapı taşı olan ailede ve ailenin bir parçasını oluşturan çocuklarda da kendine yer bulmaktadır. Bu bağlamda, çocuğun turizm ile olan ilişkisi, beklentileri ve turizmin zihinlerinde yeri turizm aktörleri için önem arz etmektedir. Çocuklardan gelecek fikirlerin turizm 
hareketliliğine sağlayacağı katkı turizm unsurları tarafından değer görmekle beraber, yönlendirmeye uygun bir yapı taşıyan çocukların konuya ilişkin gerçekte ne hissettiklerinin bilinmesi, ebeveynler ve uzmanlar tarafından da önem teşkil edecektir. (Tankuş vd., 2018: 27). Günümüzün çocukları, ailelerin satın alma kararlarında etkili olmaktadır. Tatile çıkma kararında önemsenen çocuklar, ailenin tatille ilgili bir tercihin de belirleyicisi olurken, aynı zamanda, geleceğin potansiyel turisti olarak da önemlidirler. Bu nedenle, çocukların turizme bakış açılarını bilmek, turizm ile ilgili beklentilerinin belirlenmesi yanında, turizm bilincinin belirlenmesi bakımından da gereklidir (Akoğlan-Kozak ve Özkeroğlu, 2020: 19). Son yıllara kadar turizm pazarlaması konusunda çocuklara yönelik turizm pazarına yeterince önem verilmemiştir. Ancak değişen aile yapısıyla birlikte turizm talebinde de değişimler görülmeye başlanmıştır. İnsanlar aileleri ile birlikte gerek yurt içi gerekse yurt dışı turizm faaliyetlerine katılmakta ve gidecekleri yerlere karar verirken çocuklarının isteklerini de göz önünde bulundurmaktadırlar (Tanrısever vd., 2018: 33).

Çocuk ve turizm olgusunu ele alan ulusal ve uluslararası bazda çeşitli yapılmıştır. Bu çalışmaları; turizm deneyimlerinin çocuklar tarafından algılanış biçimine yönelik yapılanlar (Yang vd., 2020; Khoo-Lattimore; 2015; Nickerson ve Jurowsk, 2001; Gamradt, 1995) olarak siralamak mümkündür. Ayrıca çalışmanın ana problemi doğrultusunda yapılan çalışmalara (Ertaş vd., 2021; Akoğlan-Kozak ve Özkeroğlu, 2020; Aytatlı vd., 2020; Wu vd., 2019; Tankuş vd., 2018; Rhoden vd., 2018) ilişkin sonuçlara aşağıda yer verilmiştir.

Ertaş vd. (2021) tarafından 7-15 yaş arasında 30 öğrenci ile yürütülen çalışmada turizm deneyimlerinin resmedilmesi istenmiştir. Çalışmada resim analizlerine göre 4 temel kategori belirlenmiş̧ir. Ekonomi ana kategorisinde, turizmin ekonomik katkıları resmedilmiş olup genel kanı pozitiftir. Kullanılan alt kategori ise sıklıkla dolar olmuştur. Sosyo-kültürel unsurları içeren ana kategoride resimler kültürel çeşitlilik üzerinde yoğunlaşmıştır. Bunun yanı sıra kültürel miras, rekreasyonel faaliyetler ve kültürel kimlik gibi alt kategoriler de oluşmuştur. Çevre unsurlarını içeren ana kategoride turizmin olumlu ve olumsuz etkileri resmedilirken, genel olarak doğal kaynaklar üzerinde durulmuştur. Görüşme bulguları da öğrencilerin turizme ve turiste bakış açılarının genel olarak pozitif olduğunu göstermiştir. Katılımcılar, turistleri arkadaş canlısı, kibar, nazik ve iyi olarak tarif edilmiştir.

Akoğlan-Kozak ve Özkeroğlu (2020) çocukların bakış açısı ile turizm kavramını irdelemişlerdir. Araştırmacılar, Uluslararası Turizm Karikatürleri yarışmasında son 5 yıldır çocuklar tarafından çizilen 204 karikatürü incelemiştir. 16 yaşına kadar çocukların yaptığı karikatürlerin incelendiği çalışma bulguları, çizilen karikatürlere göre kategorilere ayrılmakla birlikte daha çok doğa, insan ve konaklama unsurları üzerinde durulmuştur.

Aytatlı vd., (2020) tarafından yapılmış olan çalışmada 8-11 yaş grubu çocukların turizme bakış açıları çizdikleri resimlerle ortaya konmaya çalışılmıştır. 3 farklı okulda yapılan çalışma sonuçları genel olarak deniz turizmine ilişkin göstergeler içerdiği yönündedir. Buna ek olarak orman, dağ, yeşil alanlar da sıklıkla çizilen unsurlardandır.

Wu vd., (2019) Çin'deki çocukların aileleri ile yapmış oldukları tatillere ilişkin algılarını resimleme tekniği ile tespit etmeye çalışıştır. 8-11 yaş arasındaki 139 çocuğun dahil olduğu çalışmada kumdan kaleler, yüzme ve dalma, doğa ve hayvanlar resmedilmiştir. Bunlara ek olarak yemekler, bina ve ulaşım araçları da resimlerde yer almıştır.

Tankuş vd., 2018 yılında yapmış oldukları çalışmada 6-12 yaş çocukların bakış açısı ile turizm kavramını irdelemiştir. Görüşmenin kullanıldığı çalışmada çocukların turizm algısı, hayal ettikleri tatiller, konaklama işletmelerine ilişkin beklentileri tespit edilmeye çalışılmıştır. 
Rhoden vd., (2016) 9-10 yaş grubu 39 çocuktan, tatil bölgelerinde konaklama yaptıkları işletmelere ilişkin deneyimlerini resmetmesini istemiştir. Bunun yanı sıra tatil deneyimleri hakkında sorular da yönlendirilmiştir. Çalışma sonuçları genel itibari ile çocukların tatil deneyimlerinden mutlu oldukları, konaklama yaptıkları işletmelerde kendilerini iyi ve rahat hissettikleri yönünde olmuştur. Tatil bitiminde evlerine dönmek zorunda olan çocukların çizimlerinde ise mutsuz ya da ağlayan bebekler vardır.

\section{Çocuk ve Resim İlişkisi}

Sözel olmayan iletişim yöntemleri çocukların kendini ifade etmede kullandıkları önemli yollardan birisidir. Bu yöntemlerden birisi de resimdir. Resimler çocuklar için iletişimin en etkili unsurlarından birini oluşturmaktadır (Artut, 2004: 224). Çocuklar dünyalarının bir yansıması olarak resimlerinde kendine ait renk ve semboller kullanmakta (Afşaroğlu-Eren, 2017: 161) ve korkularını, duygusal problemlerini, endişelerini çizdiği resimler aracılı̆̆ıyla yansıtmaktadır. Bu nedenle resimler çocukların iç dünyası hakkında bilgiler elde etmemizi sağlamaktadır (Yavuzer, 2016: 11; Yüce, 2016: 314). Çocuklar çizdikleri resimlerde daha çok hayal ettiklerini yansıtmaktadır. Bu nedenle çizilen basit bir çizgi bile çocuk için pek çok anlamı içerebilmektedir (Çankırılı, 2012).

Çocukların ilk çizimleri karalama adını verdiğimiz çizgilerle başlamaktadır. Karalama dönemi iki yaşındaki çocukların ilk çizgileriyle başlayan dönemi kapsamaktadır. Bu dönem yaklaşık 4 yaşa kadar sürmektedir. Bu karalamalar zamanla anlamlı çizimlere dönüşmektedir. Çocukların yaşları büyüdükçe resimleri de daha gerçekçi olmaktadır (Kındap, 2005; Kırışoğlu, 2002). Karalamalar çocukların içgüdüsel olarak gerçekleştirdiği rastgele, bilinçsiz ve kontrolsüz eylemleri olarak ortaya çıkmaktadır. Çocukların bu dönemde yaptıkları karalamalar mekân kavramı bulunmaksızın kâğıt yüzeyinin her tarafına gelişigüzel bir şekilde çizilebilmektedir (Artut, 2004: 225). Karalama dönemindeki çizgilerin biçimlenmeye başladığı dönem ise şema öncesi dönemdir. Bu dönem 4-7 yaş arasını kapsamaktadır (Özönder-Aydın, 2017: 2222). Bu dönemde bilinçli bir şekilde resim yapmaya başlayan çocukların çizgileri belli bir olgunluğa ulaşmıştır. Çocukların bu dönemde çizdiği şemalar karalama döneminde olduğu gibi soyut değildir. Resimlerinde kısıtlama ve yapamama endişesi taşımayan çocukların bu dönemde çizimleri daha anlaşılabilir bir hale gelmektedir. Bu dönemdeki çocuklar, duygusal bağının daha güçlü olduğu nesneleri daha ayrıntılı bir şekilde çizme eğilimi göstermektedir. Resimlerinde ise çok fazla insan figürü çizimleri yer almaktadır (Jolley, 2010; Özönder Aydın, 2017; YamanBozdemir, 2020).

Çizim çocukluk döneminde en sevilen aktivitedir. Bu aktivite çoğu zaman yetişkinler tarafından göz ardı edilse de resim çizmek çocuklar için keyif vericidir. Resimler insan iletişiminin en temel aracı olarak kabul edilmektedir. Dolayısıyla çocukların gelişiminde de en önemli kilometre taşlarından birini oluşturmaktadır (Zlateva, 2019: 9). Resim ve çocuk birbirini tamamlayan, sürekli değişen ve gelişen olgulardır (Yaman-Bozdemir, 2020: 21). Çocuk çizimlerinin, çocuğun gelişiminin temsili bir aynası olduğu düşünülmektedir (Cherney vd., 2006: 127). Çocuklar resimler aracılığıyla öğrenme ve gelişmelerini gösterir (Stolley, 2012: 4). Çocuklar çevrelerindeki dünyayı keşfetme sürecinde kalem, kâğıt, fırça gibi araçlar ile bu keşiflerini aktarma ihtiyacı duymaktadır (Farokhi ve Hashemi, 2011: 2219). Bu nedenle resimler çocukların deneyimlerine ilişkin bilgiler edinmemizi sağlamaktadır. İlgili çalışmalara bakıldığında da çocukların çeşitli konulara ilişkin algılarının resimler aracılığıyla incelendiği görülmektedir. Yıldırım-Doğru vd. (2006) çocukların aile kavramına ilişkin algılarını resimler aracılığıyla incelemiştir. Yurtal ve Artut (2008) çocukların şiddeti algılama biçimlerini çizdikleri resimler aracılığıyla ortaya 
koymuşlardır. Türkcan (2013) yaptı̆̆ çalışmada ilköğretim öğrencilerinin verilen bir kavrama ilişkin algılarını resmetmelerini istemiş ve resimler üzerinden göstergebilimsel bir analiz yapmıştır. Şimşek-İşliyen ve İşliyen (2015) yaptıkları çalışmada çocukların medya algılarını resimler üzerinden analiz etmiştir. Bu kapsamda çocuklardan medyaya yönelik resimler yapmaları istenmiş ve resimler çözümlenmiştir. Yukay-Yüksel vd., (2015) okul öncesi dönemdeki çocukların iyi ve kötü kavramlarına ilişkin algılarını resim analizi yöntemiyle incelemiştir. Bay (2019) ise okul öncesi dönemdeki çocukların okul algılarının incelenmesi amacıyla çocuklardan resim çizmelerini istemiş ve resimler doküman olarak incelenmiştir.

\section{YÖNTEM}

Araştırmanın amacı, beş yaş grubu çocukların turizm kapsamında tatil algılarını çizdikleri resimlerle tespit edebilmektir. Bu amaç doğrultusunda çocukların turizme ilişkin bakış açılarını ve çağrışımlarını ortaya koyabilmek araştırmanın temel sorunudur. Araştırma kapsamında çocuklara turizm, tatil, seyahat gibi kavramlar anlatılmadan resimler çizilmesi istenmiştir. Konular hakkında ön bilgi verilmemesinin nedeni çocukların çizecekleri resimler konusunda kısıtlamaya gidilmemesinin yanı sıra yönlendirme yapmamaktır. Okul öncesi eğitimini sürdüren beş yaş grubu çocukların tatil algıları ve çağrışımları turistik ürünün pazarlanması ve planlaması aşamasına rol oynayabileceği düşünülmektedir. Ailelerin tatil planlarında ve satın alma davranışlarında çocukların önemi düşünüldügünde turizm işletmecilerine katkı sağlayacağı gibi, literatürde ilgili yaş grubu üzerine çalışma yapılmamış olması nedeniyle de bu boşluğu dolduracağı düşünülmektedir.

Araştırmanın çalışma grubunu okul öncesi eğitime devam eden 5 yaş grubu 23 çocuk oluşturmaktadır. Örneklem grubunun seçiminde amaçlı örneklemden yararlanılmış olup kolay ulaşılabilir nitelik taşıması gözetilmiştir. Bu kapsamda çocukların 13'ü kız, 10'u erkektir. Çalışma 2020 yılının Ocak ayında gerçekleştirilmiştir. Veri toplama aşamasında ilgili okulun yöneticisi ve çalışma yapılacak sınıfın öğretmeni ile ön görüşmeler yapılarak çalışmanın amacı ve veri toplama süreci aktarılmıştır. Bu kapsamda belirlenen günde ilgili sınıfa gidilerek öncelikle çocuklara neler yapılacağına ilişkin bilgi verilmiştir. Ardından çocuklardan tatil denilince neler algıladıklarına ilişkin bir resim çizmeleri istenmiştir. Resimlerin çizilmesinde okul öncesi öğretmeni de araştırmacılara eşlik etmiş olup genel olarak çizim süreleri bir etkinlik saatini kapsamıştır.

Çalışma kapsamında nitel yöntemler birbirlerini tamamlayacak şekilde kullanılmıştır. Bu bağlamda resimleme tekniği, içerik analizi ve görüşmeden yararlanılmıştır. Resimleme tekniği çocukların turizme bakış açılarını ortaya koymasını sağlaması amacıyla tercih edilmiştir. Bu araç, çocukların kendilerini çizimlerle ifade etmelerine olanak tanırken, hayal güçlerini de ortaya koymaktadır. Çalışma kapsamında elde edilen 23 resim, araştırmacılar tarafından arşivlenmiştir. Gerekli tarama işlemleri yapılarak resimlerin dijital ortama aktarımı sağlanmıştır. Resimleme tekniğinden yararlanarak, çocukların çizmiş oldukları unsurlar gruplandırılmıştır. Çocukların kullandıkları resimler, resimlerin özellikleri analiz edilmiştir. Ayrıca resimler demografik değişkenlerden biri olan cinsiyete göre ayrılarak resim çözümlemeleri yapılmıştır.

İçerik analizi, çocukların resmettiği unsurların kategorilere ayrılması amacıyla kullanılmıştır. İçerik analizi kapsamında araştırmacılar tarafından ana kodlar ve alt kodlar oluşturulmuştur. Çalışmada doğaya ilişkin unsurlar, gökyüzüne ilişkin unsurlar, bitkilere ilişkin unsurlar, hayvanlara ilişkin unsurlar, ulaşıma ilişkin unsurlar, eylemlere ilişkin unsurlar, konaklama ilişkin unsurlar, tatile ilişkin unsurlar, yazılı unsurlar ve diğer unsurlar olmak üzere 12 ana kategori oluşturulmuştur. Bunun dışında çocukların yapmış oldukları resimlerde kullanmış oldukları renkler; ana renkler, ara renkler ve diğer renkler olmak üzere 3 ana kategoriye ayrılmıştır. Çocuklar tarafından çizilen resimler yaş grupları da dikkate alınarak resim özellikleri 
bakımında da irdelenmiştir. Düzeleme özelliği, yer çizgisi kullanımı, gerçekçi renk kullanımı, orantılı resim özelliği ve saydam resim özelliği olmak üzere 5 kategoride incelenmiştir.

Görüşme, resimlerini tamamlayan çocukların çizdikleri şekilleri, anlatmaya çalıştıkları unsurları ve tatil deneyimlerini tespit amacı ile tercih edilmiştir. Bu nedenle çocuklara sorular sorup resmettikleri unsurlar hakkında notlar alınmıştır. Görüşmeler, bir etkinlik saatini kapsamıştır. Görüşmeler deşifre edilirken çocukların en sık kullandığı kelimeler kelime bulutu ile görselleştirilmiştir. Görüşme bulguları, doğaya ilişkin algılar, hayvanlara ilişkin algılar, konaklama işletmelerine ilişkin algılar ve tatil deneyimine ilişkin algılar olarak kategorize edilmiştir.

\section{BULGULAR}

\section{Beş Yaş Grubu Çocukların Çizimlerine İlişkin Bulgular}

Çalışmada okul öncesi dönemdeki beş yaş grubu çocukların tatil algılarının resimler aracılığıyla incelenmesi amaçlanmıştır. Çocukların resimlerine ilişkin bulgular aşağıda tablolar halinde sunulmuştur. Resimler; tatil kavramına ilişkin unsurlar, kullanılan renkler ve resim özellikleri olmak üzere üç ayrı tema altında incelenmiştir. Her bir temaya ilişkin kategoriler ve alt kategoriler belirlenmiş, her bir kategori ise ayrıca cinsiyete göre ele alınmıştır. Bu kapsamda tatil kavramına ilişkin unsurlar temasına ilişkin bulgular Tablo 1' de yer almaktadır.

Tablo 1' e bakıldığında çocukların tatil algılarına ilişkin çizimleri; doğaya ilişkin unsurlar, gökyüzüne ilişkin unsurlar, bitkilere ilişkin unsurlar, hayvanlara ilişkin unsurlar, sosyal çevreye ilişkin unsurlar, ulaşıma ilişkin unsurlar, eylemler, konaklamaya ilişkin unsurlar, tatile ilişkin unsurlar, güvenlik unsurları, yazılı unsurlar/semboller ve diğer unsurlar olmak üzere 12 kategori altında ele alınmıştır.

Doğaya ilişkin unsurlar kategorisi, çocukların resimlerinde yer alan doğal çevre unsurlarını içermektedir. Bu kapsamda çocukların resimlerinde en çok deniz $(\mathrm{n}=19)$ çizimine yer verdikleri görülmüştür. Dalga $(n=9)$, kumsal $(n=8)$ ve kum $(n=7)$ çizimleri de deniz çiziminden sonra en sık kullanılan unsurlar olmuştur. Cinsiyete göre ele alındığında ise kız ve erkek çocuklarının bu kategori altındaki çizimlerinde bir farklılaşma olduğu gözlemlenmektedir. Bu kapsamda kız çocukları 4 farklı alt kategoriye (deniz, dalga, kum ve kumsal) ilişkin çizimler yaparken erkek çocukları ise 8 farklı alt kategoriye (deniz, kumsal, dalga, kum, çakıl, dağ, şelale ve çim) ilişkin çizimler yapmıştır. Doğaya özgü çizimler toplam olarak değerlendirildiğinde çizilen resimlerde erkek çocuklarının daha fazla öğe kullandığı tespit edilmiştir.

Gökyüzüne ilişkin unsurlar ana kategorisinde genel olarak çocuklar tarafından güneş $(n=17)$ çizimine yer verilmiştir. Bunu sırasıyla bulut $(n=7)$ ve gökkuşağ $(n=1)$ çizimlerinin izlediği görülmektedir. Cinsiyet bazında bir değerlendirme yapıldığında bu kategori altında anlamlı bir farklılaşma bulunmadığ 1 görülmüştür. Kız ve erkek çocuklarının çoğunun gökyüzüne ilişkin unsurlardan güneşi ve bulutu çizdikleri görülmektedir. 1 kız çocuğu (Ç5) ise görsel 1'de de yer verildiği gibi gökkuşağını resmetmiştir. Genel bir değerlendirme yapıldığında güneş unsuru her iki cinsiyet bazında kullanılsa da (nk=10, ne=7) kız çocukları erkek çocuklarına göre çizimlerinde gökyüzüne ilişkin unsurlara daha fazla yer vermiştir. 
Tablo 1. Tatil Kavramına İlişkin Unsurlar

\begin{tabular}{|c|c|c|}
\hline \multirow[t]{2}{*}{ Kategoriler } & \multicolumn{2}{|c|}{ Cinsiyet } \\
\hline & $\mathrm{K} \mathbf{1 z}$ & Erkek \\
\hline \multicolumn{3}{|c|}{ Doğaya İlişkin Unsurlar } \\
\hline Deniz & 12 & 7 \\
\hline Dalga & 5 & 4 \\
\hline Kumsal & 3 & 5 \\
\hline Kum & 3 & 4 \\
\hline Dağ & - & 4 \\
\hline Şelale & - & 3 \\
\hline Çakıl & - & 2 \\
\hline Çim & - & 1 \\
\hline \multicolumn{3}{|c|}{ Gökyüzüne İlişkin Unsurlar } \\
\hline Güneş & 10 & 7 \\
\hline Bulut & 5 & 2 \\
\hline Gökkuşağı & 1 & - \\
\hline \multicolumn{3}{|c|}{ Bitkilere İlişkin Unsurlar } \\
\hline Ağaç & 7 & 4 \\
\hline Çiçek & 5 & 2 \\
\hline Yaprak & 3 & 1 \\
\hline Sarmaşık & 1 & - \\
\hline Orman & 1 & 1 \\
\hline Yosun & 1 & - \\
\hline \multicolumn{3}{|c|}{ Hayvanlara İliş̧kin Unsurlar } \\
\hline Balık & 3 & 6 \\
\hline Kuş & 4 & 3 \\
\hline Kedi & 2 & 2 \\
\hline Flamingo & 4 & - \\
\hline Köpek & 2 & 1 \\
\hline Kelebek & 3 & - \\
\hline Kertenkele & - & 2 \\
\hline Yllan & - & 1 \\
\hline Yengeç & 1 & - \\
\hline Maymun & 1 & - \\
\hline Salyangoz & 1 & - \\
\hline Köpekbalı̆̆ı & 1 & 1 \\
\hline Mercan & - & 1 \\
\hline \multicolumn{3}{|c|}{ Sosyal Çevreye İlişkin Unsurlar } \\
\hline Aile & 5 & 4 \\
\hline Kendi & 3 & 5 \\
\hline Arkadaş & 3 & 1 \\
\hline \multicolumn{3}{|c|}{ Ulaşıma İlisskin Unsurlar } \\
\hline Araba & 5 & 2 \\
\hline Bisiklet & 2 & - \\
\hline Gemi & - & 1 \\
\hline \multicolumn{3}{|l|}{ Eylemler } \\
\hline Yüzmek & 3 & 5 \\
\hline Güneşlenmek & 2 & 1 \\
\hline \multicolumn{3}{|c|}{ Konaklamaya İliskin Unsurlar } \\
\hline Oteller & 2 & 2 \\
\hline Bungalov & & 1 \\
\hline \multicolumn{3}{|c|}{ Tatile İliskin Unsurlar } \\
\hline Havuz & 1 & 3 \\
\hline Şemsiye & 1 & 1 \\
\hline Şezlong & 1 & - \\
\hline Deniz Yatağ & - & 1 \\
\hline Mayo-Bikini & 1 & - \\
\hline \multicolumn{3}{|c|}{ Güvenlik Unsurları } \\
\hline Cankurtaran & - & 2 \\
\hline Duba & 1 & - \\
\hline Kolluk & 1 & - \\
\hline Can Yeleği & 1 & - \\
\hline Oksijen Tüpü & - & 1 \\
\hline \multicolumn{3}{|c|}{ Yazilı Unsurlar-Semboller } \\
\hline Kalp & 2 & - \\
\hline İsimler & 2 & - \\
\hline Artı & 1 & - \\
\hline Diğer Unsurlar & & \\
\hline Türk Bayrağı & 2 & 1 \\
\hline Rüzgârgülü & 1 & - \\
\hline
\end{tabular}


Görsel 1. Beş Yaş Grubu Çocukların Doğaya ve Gökyüzüne İlişkin Çizdiği Resimler

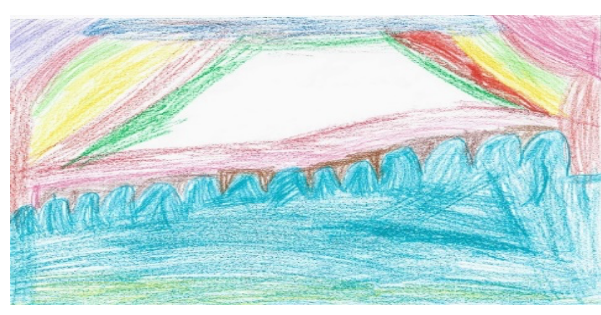

Ç5: Gökkuşağı Çizimi

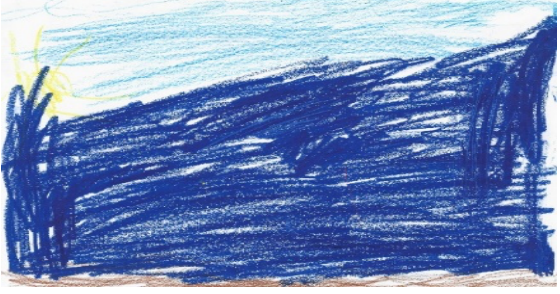

Ç19: Deniz-Güneş-Gökyüzü Çizimi

Bitkilere ilişkin unsurlar kategorisi kapsamında çocukların en çok ağaç $(n=11)$ çizimine yer verdikleri görülmektedir. Cinsiyete göre ele alındığında kız ve erkek çocuklarının bu kategori altındaki çizimlerinde bir farklılaşma vardır. Bu kapsamda kız çocuklarının 6 alt kategoriye göre çizimler yaptıkları, erkek çocuklarının ise 3 kategoriye ilişkin çizimler yaptıkları belirlenmiştir. Kız çocukları sırasıyla ağaç $(n=7)$, çiçek $(n=5)$, yaprak $(n=3)$, sarmaşık $(n=1)$, orman $(n=1)$ ve yosun $(n=1)$ çizimleri yaparken, erkek çocukları ise ağaç $(n=4)$, çiçek $(n=2)$, yaprak $(n=1)$ ve orman $(n=1)$ çizimleri yapmışır. Bitkilere ilişkin kategoride kız çocuklarının daha fazla unsura yer verdiği, erkek çocuklarının bu kategorideki çizimlerinin daha sınırlı kaldığı görülmüştür. Kız çocukları sarmaşık ve yosun gibi unsurları çizerken, erkek çocukları bu unsurlara yer vermemiştir.

Hayvanlara ilişkin unsurlar kategorisi kapsamında çocukların çizimlerinde en çok balık $(n=9)$ ve kuş $(n=7)$ çizimleri yer almıştır. Cinsiyete göre inceleme yapıldığında kız ve erkek çocukların bu kategorideki çizimlerinde bir farklılaşma olduğu gözlemlenmektedir. Kız çocukları 10 farklı hayvan çizimine yer verirken, erkek çocukları 8 farklı hayvan çizimi yapmıştır. Kız çocukları, en çok kuş $(n=5)$, flamingo $(n=4)$, kelebek $(n=3)$, balık $(n=3)$, köpek $(n=2)$ ve kedi $(n=2)$ çizmiştir. Bunun yanı sıra erkek çocuklarından farklı olarak flamingo, kelebek, yengeç, maymun ve salyangoz gibi hayvanlara da yer verdikleri belirlenmiştir. Erkek çocukları, sıklıkla balık $(n=6)$, kuş ( $n=3)$, kedi $(n=2)$ gibi hayvanları resmetmiştir. Erkek çocukları ise kertenkele, yılan ve mercan çizimleri ile kız çocuklarından farklılık göstermiştir.

Görsel 2. Beş Yaş Grubu Çocukların Bitki ve Hayvanlara İlişkin Çizdiği Resimler

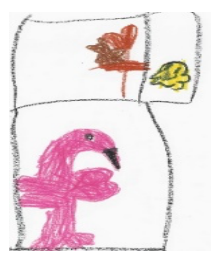

Ç11: Çiçek, Flamingo, Kuş ve Kelebek

Çizimi

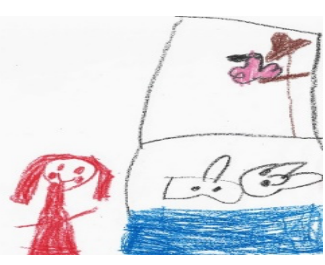

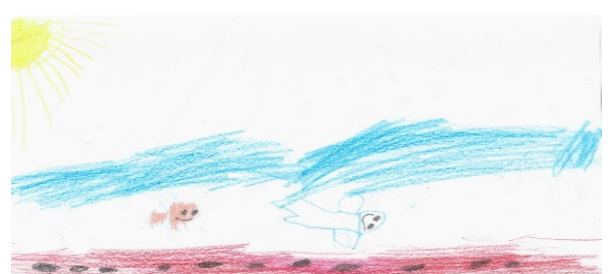

Ç7: Balık Çizimi

Sosyal çevreye ilişkin unsurlar kategorisi, çocukların yakın çevresine ilişkin çizimlerini içermektedir. Bu kategori kapsamda çocukların en çok ailesine $(n=9)$, kendisine $(n=8)$ ve arkadaşlarına $(n=4)$ ilişkin çizimler yaptığı görülmektedir. Cinsiyete göre ele alındığında kız ve erkek çocuklarının bu kategori altındaki çizimlerinde bir farklılaşma olduğu gözlemlenmektedir. Bu kapsamda kız çocuklarının sırasıyla aile $(n=5)$, arkadaş $(n=3)$ ve kendilerinin $(n=3)$ çizimlerini 
yaptığı, erkek çocuklarının ise sırasıyla en çok kendisini $(n=5)$ ve ailesini $(n=4)$ çizdiği belirlenmiştir. Öğelerin resimlerde kullanılma şekilleri incelendiğinde kız çocuklarının daha çok çekirdek ailesine yer verdikleri, erkek çocuklarının ise annelerini ya da babalarını kendileri ile çizdikleri görülmüştür. Ulaşıma ilişkin unsurlar kategorisi çocukların çizimlerinde yer alan ulaşım araçlarına ilişkin çizimlerini içeren beşinci kategoridir. Bu kategori kapsamında çocukların çizimlerinde sırasıyla en çok araba $(n=7)$ ve bisiklet $(n=2)$ çizimlerinin bulunduğu görülmektedir. Cinsiyete göre ele alındığında kız ve erkek çocuklarının bu kategori altındaki çizimlerinde bir farklılaşma olduğu gözlemlenmektedir. Bu kapsamda kız çocuklarının daha çok araba $(n=5)$ ve bisiklet $(n=2)$ çizimi yaptıkları görülürken, erkek çocuklarının çizimlerinde çok fazla ulaşım araçlarına yer vermedikleri, 1 çocuğun diğerlerinden farklı olarak gemi çizdiği belirlenmiştir.

Görsel 3. Beş Yaş Grubu Çocukların Çizdiği Resimler

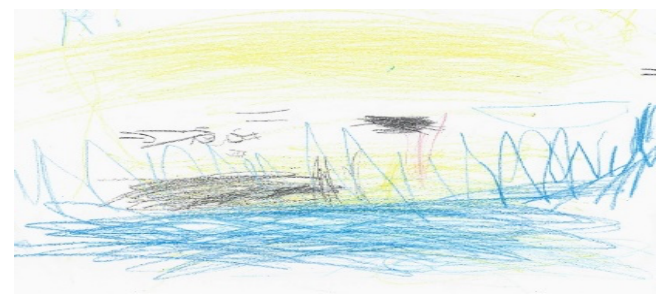

Ç23: Anne ve Kendisinin Çizimi, Gemi Çizimi

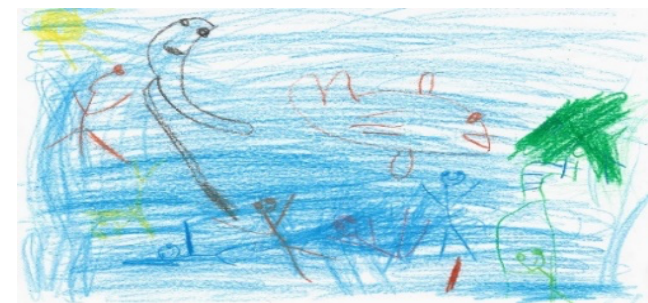

Ç12: Ailesinin Çizimi

Eylem unsurları kategorisinde, çocuklar yüzmek ve güneşlenmek gibi eylemleri resmetmiştir. Erkek çocukları, sadece yüzme ( $n=5)$ eylemini, kız çocukları ise yüzme $(n=3)$ ve güneşlenme $(n=3)$ eylemlerini çizmiştir. Resimler incelendiğinde erkek çocuklarının yüzme eylemini $(n=3)$ daha çok havuzda resmettiği görülürken, kız çocuklarından sadece 1'inin havuzda yüzme eylemini çizdiği görülmüştür. Konaklamaya ilişkin unsurlar kategorisi, çocukların çizimlerinde yer alan konaklama alanlarına ilişkin çizimlerini içermektedir. Bu kategori kapsamında çocukların en çok otel çizimi yaptıkları, bir çocuğun ise bungalov çizimine yer verdiği görülmektedir. Genel itibari ile otel çizimleri evi andırır nitelik taşımaktadır. Kız çocuklarının sadece otel çizimine yer verdiği, erkek çocuklarının ise otel ve bungalov çizimlerini yaptıkları belirlenmiştir. Tatile ilişkin unsurlar kategorisi, çocukların çizimlerinde yer alan tatil unsurlarına ilişkin çizimlerini içermektedir. Bu kategori kapsamında çocukların en çok havuz $(n=4)$ çizimi yaptıkları görülmektedir. Tatile ilişkin unsurlarda şemsiye $2 \mathrm{kez}(\mathrm{nk}=1$, ne=1), şezlong $1 \mathrm{kez}(\mathrm{nk}=1)$ deniz yatağ $1 \mathrm{kez}(\mathrm{ne}=1)$ ve bikini 1 kez $(n k=1)$ resmedilmiştir.

Görsel 4. Beş Yaş Grubu Çocukların Çizdiği Resimler

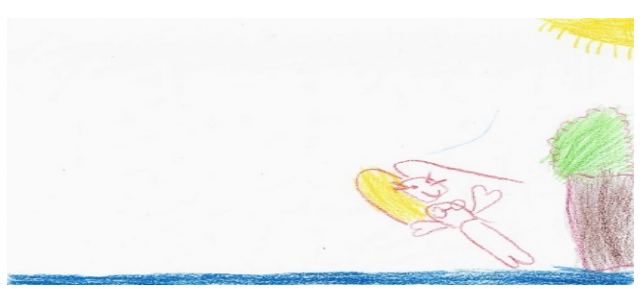

Ç1: Bikini ve Güneşlenme Çizimi

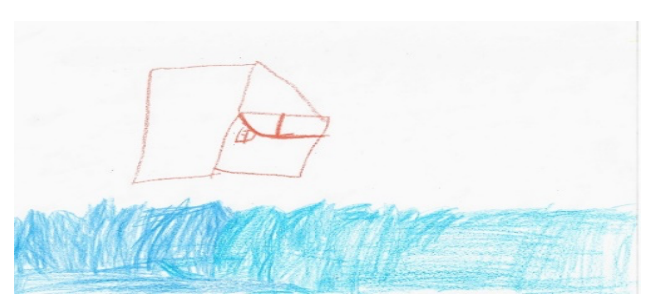

Ç13: Otel Çizimi 


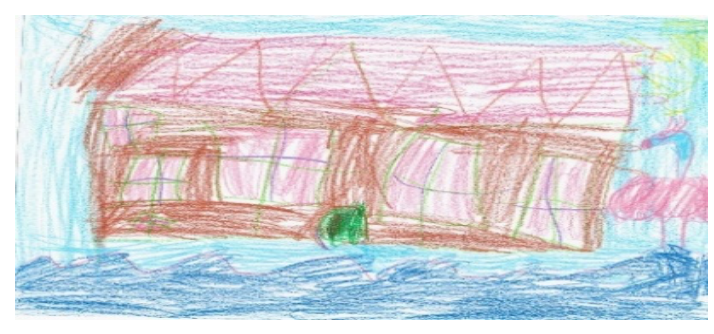

Ç15: Bungalov Çizimi

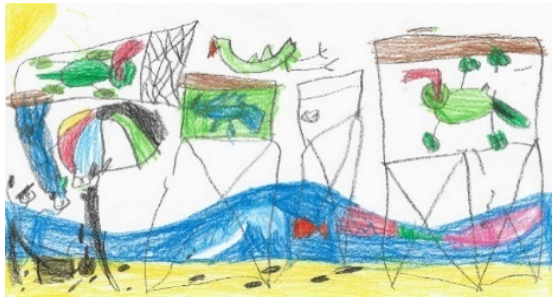

Ç4: Şemsiye ve Deniz Yatağı Çizimi

Güvenlik unsurları kategorisi, tatilde yer alan güvenlik unsurlarına ilişkin çizimleri içermektedir. Bu kategori kapsamında çocukların en çok cankurtaran $(n=2)$ çizimi yaptıkları görülmüştür. Kız çocukları, erkek çocuklarına göre 3 farklı unsura yer verirken bu kategoride yer alan unsurların sayısal dağılımı diğer kategorilere göre sınırlı kalmıştır. Kız çocukları duba, kolluk ve can yeleği çizimleri yaparken erkek çocukları cankurtaran ve oksijen tüpü çizmiştir. Yazılı unsurlarsemboller kız çocuklarının çizimlerinde kullanılırken erkek çocuklarının hiçbiri yazılı unsurları ya da sembolleri kullanmamıştır. Bu kapsamda 2 kız çocuğu kalp sembolü çizerken, 1 kız çocuğu artı sembolü çizmiş, $1 \mathrm{k}$ z çocuğu da sadece ismini yazmıştır. Diğer unsurlar kategorisinde ise çocukların çizimlerinde Türk bayrağı $(n=3)$ yer almıştır. Bunun yanı sıra bir kız çocuğu da rüzgâr gülü çizmiştir.

Görsel 5. Beş Yaş Grubu Çocukların Çizdiği Resimler

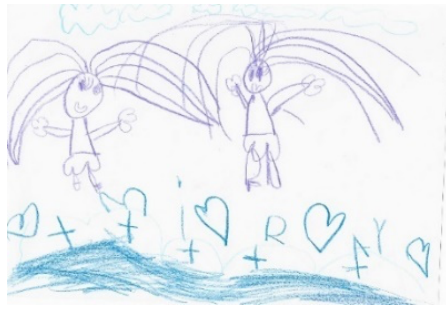

Ç16: Yazılı Unsurların Çizimi

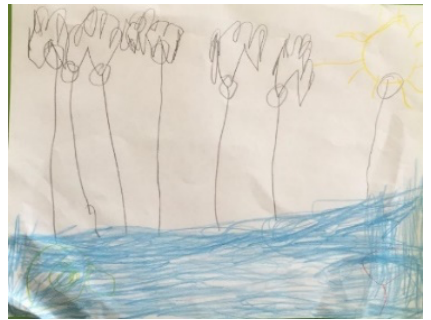

Ç18: Rüzgâr Gülü Çizimi

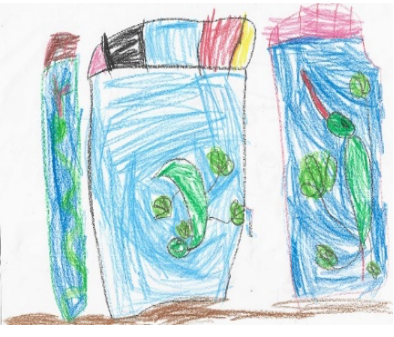

Ç2: Duba ve Cankurtaran Çizimi

Çalışmanın ikinci teması kullanılan renkler ve çizim özellikleridir. Çocukların resimlerinde kullandıkları renkler; ana renkler, ara renkler ve diğer renkler alt kategorileri altında incelenmiştir. Bu kapsamda çocukların resimlerinde kullandıkları renklere ilişkin bulgular Tablo 2 ' de sunulmaktadır.

Tablo 2'ye göre çocuklar, resimlerinde çoğunlukla ana renk kullanımına yer vermiştir. Çocukların çoğunun $(n=21)$ mavi rengini kullandıkları görülmektedir. Mavi renk, genellikle gökyüzü, deniz, havuz, bulut ve şelale çizimlerinde kullanılmıştır. Buna ek olarak 2 çocuk güneş çiziminde de mavi rengi kullanmıştır. Ana renk kullanımında sarı 19 kez (ne=10, nk=9), kırmızı ise $9 \mathrm{kez}(\mathrm{ne}=6, \mathrm{nk}=3$ ) kullanılmıştır. Sarı renk; güneş, duba, kum, çiçek ve saç çizimlerinde kullanılırken kırmızı renk ise mercan, çocuk, şemsiye, çatı ve çiçek çizimlerinde yer almıştır. Erkek çocuklarının ana renkleri seçerek çizdikleri unsurların sayısı 25 iken, kız çocuklarının çizdikleri unsur sayısı 24'tür. Çocuklar ara renklerden, yeşil $(n=9)$, mor $(n=5)$ ve turuncuyu $(n=5)$ tercih etmiştir. Yeşil renk; ağaçlar, orman, çiçek, hayvan ve sarmaşık çizimlerinde, mor renk; çiçek 
ve insan çizimlerinde, turuncu renk; kumsal, balık ve güneş çizimlerinde kullanılmıştır. Çocuklar diğer renkleri de kullanmışlardır. Bu kapsamda çocuklar siyah $(n k=4, n e=7)$, pembe $(n k=8, n e=2)$, kahverengi $(n k=3$, ne $=5)$, lacivert $(n k=3, n e=4)$ ve ten rengini $(n e=2)$ kullanmıştır. Genel olarak değerlendirme yapılığında kız çocuklarının sırasıyla en çok mavi, sarı ve pembe renklerini, erkek çocuklarının ise sırasıyla en çok sarı, mavi ve siyah renklerini kullandıkları görülmektedir. Ayrıca erkek çocuklarının ten rengini kullandığı, kız çocuklarının ise ten rengi kullanımına yer vermediği belirlenmiştir.

Tablo 2. Resimlerde Kullanılan Renkler ve Resim Özellikleri

\begin{tabular}{lcc}
\hline Kullanılan Renkler & Kiz & Erkek \\
\hline Ana Renkler & 12 & 9 \\
Mavi & 9 & 10 \\
Sarı & 3 & 6 \\
Kırmızı & & \\
Ara Renkler & 4 & 5 \\
Yeşil & 3 & 2 \\
Mor & 2 & 3 \\
Turuncu & & \\
Diğer Renkler & 4 & 7 \\
Siyah & 8 & 2 \\
Pembe & 3 & 5 \\
Kahverengi & 3 & 4 \\
Lacivert & - & 2 \\
Ten Rengi & & \\
\hline Resim Özellikleri & Kiz & Erkek \\
\hline Düzleme Özelliği & 5 & 6 \\
Yer Çizgisi Kullanimı & 6 & 4 \\
Gerçekçi Renk Kullanımı & 4 & 5 \\
Orantılı Resim Çizimi & 6 & 1 \\
\hline
\end{tabular}

Çalışmanın üçüncü teması resim özellikleridir. Çocukların resimlerinde görülen resim özellikleri, ilgili yaş grubu bağlamında literatür doğrultusunda ele alınmıştır. Bu kapsamda şema öncesi döneme ait resim özellikleri; saydam resim özelliği, yer çizgisi kullanımı, gerçekçi renk kullanımı, orantılı resim çizme ve düzleme özelliği bağlamında incelenmiştir. Çocukların resimlerindeki çizim özelliklerine bakıldığında, resimlerde en çok düzleme özelliğinin görüldüğü belirlenmiştir. Sırasıyla 10 çocuğun resminde yer çizgisi özelliği bulunduğu ve 9 çocuğun resminde gerçekçi renk kullanımına yer verdiği görülmektedir. 7 çocuğun resminde orantılı resim özelliği, 4 çocuğun resminde ise saydam resim özelliği olduğu belirlenmiştir. Cinsiyete göre kız çocuklarının çizimlerinde sırasıyla en çok yer çizgisi kullanımı, orantılı resim çizimi ve düzleme özellikleri bulunurken, erkek çocuklarının çizimlerinde ise sırasıyla düzleme özelliği, gerçekçi renk kullanımı ve yer çizgisi özellikleri vardır. 
Görsel 6. Beş Yaş Grubu Çocukların Çizdiği Resimler

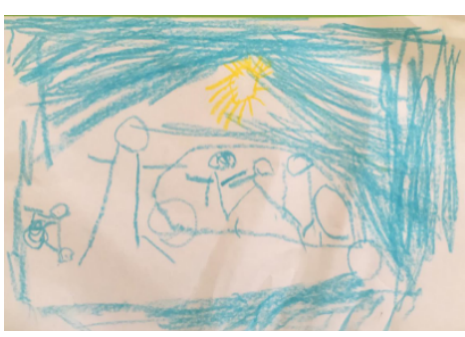

Ç10: Saydam Resim Özelliği

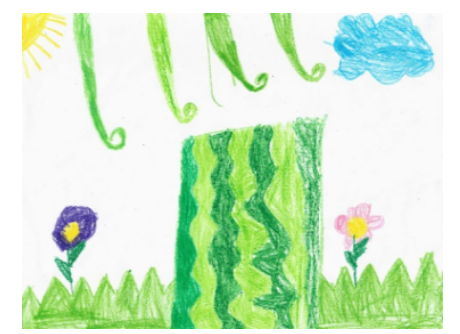

Ç6: Gerçekçi Renk Kullanımı

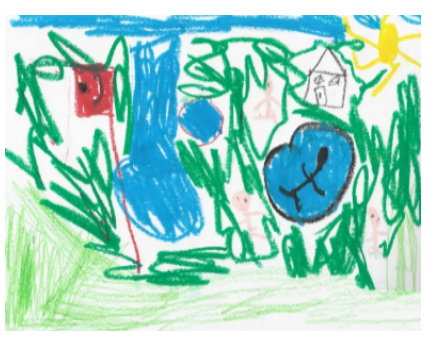

Ç9: Düzleme Özelliği

\section{Beş Yaş Grubu Çocukların Tatil Algılarına İlişkin Bulgular}

Çalışmada okul öncesi eğitime devam eden beş yaş grubu çocukların tatil çağrışımlarına yönelik resim analizleri çocukların bu konudaki tatil algılarını görüşme ile de tespit etmeyi beraberinde getirmiştir. Görüşmeler çözümlendiğinde çocukların tatil algılarının, önceden yaşadıkları tatil deneyimleriyle ilişkili olduğu görülmüştür. 18 çocuğun çizdikleri resimlerde daha önce yaşamış oldukları tatil deneyimlerini aktardıkları belirlenmiştir. Görüşmeler incelendiğinde çocuklar 27 farklı anahtar kelime kullanmış olmakla birlikte en sık kullandıkları kelimelerin dağılımı deniz, güneş ve sıcak şeklinde olmuştur.

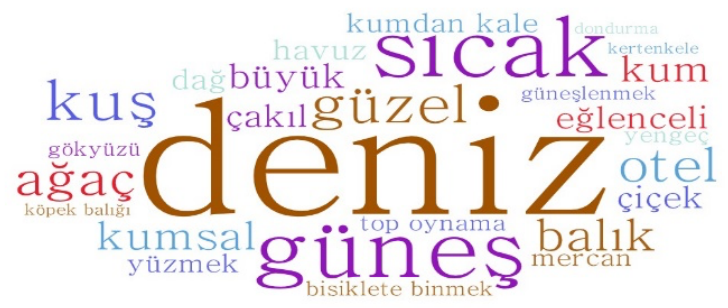

Şekil 1. Görüşmeye İlişkin Kelime Bulutu

a) Doğaya İlişkin Algılar: Beş yaş grubu çocuklar genel olarak (n=15) tatil algılarını doğa üzerine şekillendirmiştir. Deniz, güneş, ağaç ve kumsallar çocuklar tarafından görüşme esnasında en sık tekrarlanan unsurlar olmuştur. Çocuklar tatil algılarını betimlerken sıfatlardan yararlanmıştır. Sıcak güneş, mavi deniz, büyük ağaçlar gibi betimleyici unsurları kullanmalarının yanı sıra güzel betimlemesi de sıklıkla ( $\mathrm{n}=11)$ yapılmıştır.

"Tatilde deniz, sıcak güneş, ağaçlar, tatlı meyveler vardı. Çok güzel meyveleri olan ağaçlar vardı. Denize girmiştik." (Ç3)

"Tatil deniz, kum, güneş, denizde yüzmek ve güzel yemekler demek. Denizin kocaman dalgaları olur. Bizde bu dalgalarla oyunlar oynarı." (Ç12)

"Benim bir tane deniz kıyafetim var. Onunla tatilde yüzmüştüm. Denizin arkasında ağaçlar vardı. Bir de güneş çok sıcaktı." (Ç19)

b) Hayvanlara İlişkin Algılar: Çocukların tatil algılarında sıklıkla üzerinde durdukları ikinci kategori hayvanlara ilişkindir. Balıklar $(n=12)$ ve kuşlar $(n=10)$ sık tekrarlanan unsurlarken, köpek balığı $(n=5)$, yengeç $(n=4)$ ve mercan $(n=3)$ gibi hayvanlar da sıralanmıştır. 2 çocuk ise kertenkele gördüklerinden bahsetmiştir. 
"Tatilde içinde bir sürü farklı balığın olduğu bir denizdeydik. Kumsalda çakıllar vard. Kuşlar uçuyordu. Bir tane de kertenkele görmüştüm." (Ç21)

"Tatilde ailemle birlikte denize gitmiştik. Orada bir sürü balık ve köpek balığı görmüştüm. Tatil aklıma deniz, köpek balı̆̆ı, balıkları getiriyor."(Ç7)

c) Konaklama İşletmelerine İlişkin Algılar: Beş yaş grubu çocuklar, tatil algılarına ilişkin yapılan görüşmede üçüncü ana kategori olarak konaklama işletmelerinden bahsetmişlerdir. 6 çocuk konaklama işletmeleri hakkında bilgiler verirken kaldıkları otellerde aldıkları hizmetlerden de bahsetmiştir. Otellerin büyük olması, yemeklerin güzel olması, otelin havuzunun olması genel olarak üzerinde durulan unsurlardır.

"Tatilde en çok otelleri seviyorum. Kocaman bir oteldi. Kendi denizi vardı. Kumu çok güzeldi. Otelin içinde bir de hayvanat bahçesi vardı. Oraya gitmiştik annemle."(Ç1)

"Tatilde otele gitmiştik. Otelde çok güzel yemekler ve pastalar veriyorlar. İstediğim zaman dondurma yiyebiliyordum." (Ç5)

d) Tatil Deneyimlerine İlişkin Algılar: Beş yaş grubu çocukların üzerinde en az durduğu unsur tatil deneyimlerine ilişkindir. Çocuklar, tatilde yaptıkları faaliyetleri bisiklete binmek, güneşlenmek, denizde ve havuzda yüzmek olarak sıralamıştır.

"Tatilde deniz yatağıyla havuzda ve denizde yüzeriz. Denizde dalga olunca çok eğlenceli oluyor." (Ç20)

"Annem, babam, ben ve kardeşim arabayla denize gitmiştik. Bisikletimi de aldık. Denide yüzdüm ve bisiklete bindim. Gökyüzünde sıcacık güneş vardı." (Ç9)

\section{SONUÇ ve TARTIŞMA}

Çalışmada turizm kavramından yola çıkılarak okul öncesi dönemdeki beş yaş grubu çocukların tatil algılarına ilişkin çağrışımların resimler aracılığıyla incelenmesi amaçlanmıştır. Bu kapsamda çocukların çizimleri aracılığıyla tatil algıları analiz edilmiştir. Ayrıca resimlerden elde edilen bulguları desteklemek amacıyla tatil algılarına yönelik olarak çocuklarla görüşme gerçekleştirilmiştir. Çalışmanın sonuçları resim analizi ve görüşme bulguları altında ele alınmıştır. İlgili çalışmalara bakıldığında da çocukların çeşitli konulara ilişkin algılarının resimler aracıllğı̆yla incelendiği görülmektedir (Yıldırım-Doğru vd., 2006; Yurtal ve Artut, 2008; Türkcan, 2013; Şimşek-İşliyen ve İşliyen, 2015; Tankuş, 2018; Yukay-Yüksel vd., 2015; Bay, 2019). Çalışmada çocukların çizimlerinden yola çıkılarak resimler üç ana tema altında analiz edilmiştir. Bu kapsamda çalışmanın sonuçları tatil kavramına ilişkin unsurlar, resimlerde kullanılan renkler ve resim özellikleri temaları altında ele incelenmiştir.

Tatil kavramına ilişkin unsurlar teması on iki kategoriden oluşmaktadır. Çocukların resim analizleri bütüncül bir perspektif ile incelendiğinde daha çok doğaya ilişkin unsurları içerdiği görülmüştür. Çocukların çoğu tatil kavramı için deniz unsurunu kullanmıştır. Gökyüzüne ilişkin unsurlarda güneş kullanılırken, bitkilere ilişkin unsurlarda genel çizimler ağaçlara yer vermek yönünde olmuştur. Çocuklar, hayvanlara ilişkin kategoride çeşitli çizimlere yer vermiştir. Kategoriler arasında en fazla farklı çizimin yapıldığı kategori de hayvanlara aittir. Balıklar ve kuşlar bu kategoride en sık çizilen unsurlardır. Çocukların çizimleri incelendiğinde tatil algılarında sosyal çevrelerine ilişkin unsurlar bulunduğu görülmektedir. Bu kapsamda çocukların daha çok ailelerini çizdikleri belirlenmiştir. Bazı çocuklar resimlerinde ulaşım araçlarına yer vermiştir. Bu kapsamda ulaşım araçlarının çoğunu arabalar oluşturmaktadır. Tatilde yapılan eylemlere ilişkin unsurlar kısıtlı kalmakla birlikte yüzmek ve güneşlenmek olarak resmedilmiştir. Konaklamaya ilişkin unsurlarda çocukların daha çok otel çizimine yer verdikleri görülmektedir. Tatile ilişkin unsurlarda çoğunlukla havuz çizimi bulunurken, tatil süresince 
güvenliklerini sağlayacak cankurtaran, duba, kolluk, can yeleği ve oksijen tüpü gibi unsurlar da resimlerde yer almıştır. Yazılı unsurlar ve semboller çocukların çok azı tarafından kullanılmıştır. Resimlerde bu unsurları kullanan çocuklar kalp, artı gibi semboller kullanmanın yanı sıra kendi isimlerini de yazmışlardır. Çocuklar tatillerine ilişkin resimlerinde Türk Bayrağı ve rüzgâr gülleri çizse de bu unsurlar da sınırlı düzeydedir. 12 kategori genel olarak değerlendirildiğinde, tatilin çocuklara güneş, deniz, dalga, kumsal, ağaç, balık, kuş, aile ve yüzme gibi öğeleri çağrıştırdığı görülmüştür. Günümüzde çocukların ailelerin tatil kararlarındaki etkisi giderek artmaktadır. Bu nedenle çocukların tatile ilişkin bakış açılarını bilmek önem taşımaktadır (Çakıcı ve İyitoğlu, 2011). İlgili çalışmalara bakıldığında çocukların turizm ve tatil kavramlarına ilişkin çizimlerinde daha çok doğa, insan ve konaklama üzerinde durulduğu görülmektedir (Akoğlan-Kozak ve Özkeroğlu, 2020; Aytatlı vd., 2020). Çalışma sonuçları, doğa kavramını üzerinde durulması yönünden diğer araştırmalar ile benzerlik gösterse de insan ve konaklamaya ilişkin unsurların dağılımı bakımından farklılıklar taşımaktadır. Kahyaoğlu ve Kırıktaş (2016) tarafından yapılan çalışmada çocukların doğayı orman, yeşil alan, gökkuşağı gibi kavramlarla algıladıklarını ortaya koymaktadır. Semiz ve Sözer-Çapan (2019) ise yaptıkları çalışmada çocukların resimlerinde doğaya ilişkin en çok güneş, bulut, ağaç, çiçek, çimen, kuş gibi unsurları resmettikleri sonucuna ulaşmışlardır. Çalışma sonuçları bu açıdan araştırmacıların bulguları ile benzerlik göstermektedir.

Resimde kullanılan renkler ve çizim özellikleri teması incelendiğinde çocukların resimlerinde en çok mavi rengi kullandıkları belirlenmiştir. Mavi rengin ise gökyüzü çizimi, bulut çizimi, deniz ve havuz çizimlerinde sıklıkla kullanıldığı görülmektedir. Bunun yanı sıra çocuklar sırasıyla sarı, siyah, pembe ve yeşil renklerini de kullanmışlardır. Resim özellikleri temasından elde edilen sonuçlara göre ise çocukların resimlerinde en çok düzleme özelliğinin görüldüğü belirlenmiştir. Gerçekçi renk kullanımı ve yer çizgisi kullanımına da resimlerde sıklıkla karşılaşılmıştır. Çalışmada çocuklar tarafından kullanılan renkler bir bütün olarak değerlendirildiğinde sonuçlar Aktın (2018) ve Yukay-Yüksel vd., (2015) gibi araştırmacıların ulaşmış oldukları sonuçlar ile benzerlik göstermektedir. Yukay-Yüksel vd., (2015) yaptıkları çalışmada çocukların doğayı tanımlamak için kullandıkları resimlerinde en çok mavi, kırmızı, sarı, yeşil, mor ve turuncu renklerini kullandığını ortaya koymuştur. Aktın (2018) yaptığı çalışmada çocukların genel olarak nesneleri niteliklerine uygun olan renklerle gerçekçi bir şekilde kullandıklarını, çocukların resimlerinde daha çok kırmızı, sarı, açık yeşil, mor, açık mavi ve siyah renklerini tercih ettiklerini ortaya koymuştur.

Çalışma sonuçları resim özellikler bakımdan ele alındığında Şener (2018), Metin ve Aral (2012) gibi araştırmacılar tarafından yapılan çalışma sonuçları ile benzerlik taşımaktadır. Şener (2018) yaptıkları çalışmada 4-7 yaş arasındaki çocukların yapmış oldukları çizimlerde içinde bulundukları dönemin özelliklerini yansıttığını ortaya koymuştur. Bu kapsamda çocukların çizimlerinde gerçeğe yakın formlar oluşturdukları, çizimlerinde daha çok önden çizimlere yer verdikleri, resimlerinde saydam resim özelliğinin bulunduğu, çocukların çoğunun gerçek renkleri kullandığı belirtilmiştir. Çocukların resimlerinde daha çok insan, güneş, bulut, çiçek, gökkuşağı, ağaç ve hayvan figürlerine yer verdikleri ve çizimlerinde en çok kırmızı, mavi ve mor renklerini kullandıkları sonucuna ulaşmışlardır. Metin ve Aral (2012) yaptıkları çalışmada 4-7 yaş arasındaki çocukların resimlerinin şema öncesi dönemin özelliklerini taşıdığını, çocukların resimlerinde daha çok kendileri için önemli olan unsurlara yer verdikleri, nesnelerin daha çok önden çizimlerine yer verdikleri ortaya konulmuştur.

Çocukların tatil algılarına ilişkin görüşmeler incelendiğinde ise tatil algılarının daha çok önceden yaşadıkları tatil deneyimleriyle ilişkili olduğu görülmektedir. Bu kapsamda çocukların çoğunun daha önce yaşamış oldukları tatil deneyimleri kapsamında bir tatil tanımı yaptıkları sonucuna varılmıştır. Görüşmeler incelendiğinde çocukların en sık tekrarladığı unsurlar deniz, güneş ve 
sıcak kelimeleri olmuştur. Çocuklar tatile ilişkin görüşmelerde de en çok doğaya ait algılar üzerinde durmuştur. Deniz, güneş ve ağaçlar en sık kullanılan öğelerdir. Resimlerde çizilen unsurlar da göz önüne alındığında bulguların paralellik gösterdiği görülmüştür. Çocuklar, görüşmeler esnasında hayvanlara vurgu yapmıştır. Çizdikleri resimlere benzer olarak kuşlar ve balıklar en çok bahsedilen öğeler olmuştur. Görüşme sonuçlarından bir diğeri ise çocukların konaklama işletmelerine ilişkin yaptıkları betimlemelerdir. Çocuklar, otellerin fiziksel özellikleri ve sunulan hizmetler hakkında görüşler bildirmiştir. Tatil deneyimlerine ilişkin sonuçlarda bisiklete binmek, güneşlenmek ve yüzmek gibi faaliyetler sıralanmıştır.

\section{KAYNAKÇA}

Akoğlan-Kozak M. ve Özkeroğlu, Ö. (2020). Çocuk Gözüyle Turizm: Turizm Karikatürleri Üzerinden Bir Değerlendirme. Turizm Akademik Dergisi, 7(2): 19-36.

Akoğlu, T. (1971). Dünyada ve Bizde Turizm Dünü ve Bugün. Ankara: Varlık Yayınevi.

Afşaroğlu-Eren, E. (2017). Çocuğun Kendi Dili İçinden Resmini Değerlendirmek-Duygu ve Renk Çemberi ile Çocuk Resimlerinin Değerlendirilmesi. Uluslararası Beşerî Bilimler ve Eğitim Dergisi, 3(2): 159-182.

Aktın, K. (2018). Sığınmacı Çocukların Mutluluk Temalı Resimlerinden Yansımalar. Elementary Education Online, 17(3): 1524-1547.

Archer, B. and Cooper, C. (1994). The Positive and Negative Impact of Tourism. In: Theobald, W. (Ed.) Global Tourism İçinde (ss: 73-91). Oxford: The Next Decade Butterworth Heinnemann.

Artut, K. (2004). Okul Öncesi Resim Eğitiminde Çocukların Çizgisel Gelişim Düzeylerine İlişkin Bir İnceleme. Çukurova Üniversitesi Sosyal Bilimler Enstitüsü Dergisi, 13(1): 223-234.

Aytatlı, B., Kuzulugil, A. C., Demircioğlu-Yıldız, N. ve İspirli, N. S. (2020). Çocukların Aile Turizmindeki Deneyimleri: Erzurum Kenti Örneği. Atatürk Üniversitesi Sosyal Bilimler Enstitüsü Dergisi, 24(1): 263-278.

Barutçugil, İ. S. (1984). Turizm İşletmeciliği Gözden Geçirilmiş İkinci Baskı. Bursa: Uludağ Basımevi.

Bay, D., Geyik, Ş. ve Çalışkan, Y. (2019). Okul Öncesi Dönem Çocuklarının Okul Algılarının Belirlenmesi. Ihlara Ĕ̆ itim Araştırmaları Dergisi, 4(1): 1-17.

Berneceker, P. (1968). Die Entwicklung des Fremdenverkehr in Osterreich. In Hermann Schnell (Ed). Vienna: Osterreic 50 Jahre Republik.

Cherney, I. D., Seiwert, C. S., Dickey, T. M. and Flichtbeil, J. D. (2006). Children's Drawings: A Mirror to Their Minds. Educational Psychology, 26(1): 127-142.

Çakıcı, A. ve İyitoğlu, V. (2011). Tatil Kararlarında Çocukların Etkisine Göre Antalya'ya Gelen Ailelerin Pazar Bölümlerine Ayrılması. Pazarlama ve Pazarlama Araştırmaları Dergisi, 4(8): 1-20.

Çankırılı, A. (2012). Çocuk Resimlerinin Dili. İstanbul: Zafer Yayınları. 
Çoruh, S. (1952). Turizm ve Türkiye Turizmi. Ankara: Örnek Matbaası.

Dann, G. and Cohen, E. (1991). Sociology and Tourism. Annals of Tourism Research, 18(1): 155-169.

Ertaş, Ç., Ghasemi, V. and Kuhzady, S. (2021). Exploring Tourism Perceptions of Children Through Drawing. Anatolia, 32: 1-12.

Farokhi, M. and Hashemi, M. (2011). The Analysis of Children's Drawings: Social, Emotional, Physical, and Psychological Aspects. Procedia-Social and Behavioral Sciences, 30: 2219-2224.

Gamradt, J. (1995). Jamaican Children's Representations of Tourism, Annals of Tourism Research, 22(4): 735-762.

Goeldner, R. C., Ritchie, B. R. J. and McIntosh, R. W. (2000). Tourism: Principles, Practices, Philosophies. New York: John Wiley Sons Inc.

Gunn, C. (1988). Vacationscape: Designing Tourist Regions. New York: Van Nostrand Reinhold.

Hunziker, W. and Krapf, K. (1942). Grundriss Der Allegemeinen Fremdenverkehrslehre. Zurich.

Jayapalan, N. (2001). An Introduction to Tourism, India: Atlantic Publishers and Distributors.

Jolley, R. P. (2010). Children and Pictures, Drawing and Understanding. John Wiley \& Sons Publication.

Kahyaoğlu, M. ve Kırıktaş, H. (2016). Ortaöğretim ve Üniversite Öğrencilerinin Doğa Kavramına İlişkin Algılarının Metafor Analizi Yoluyla İncelenmesi. Marmara Coğrafya Dergisi, (33): 58-76.

Khoo-Lattimore, C. (2015). Kids on Board: Methodological Challenges, Concerns and Clarifications When Including Young Children's Voices in Tourism Research. Current Issues in Tourism, 18(9): 845-858.

Kındap, S. (2005). Çocuk Çizimlerinde Temsil ve İfade. Türk Psikoloji Dergisi, 25- 43.

Kırışoğlu, O. T. (2002). Sanatta Eğitim, Ankara: Pegem Yayıncllık.

Kozak, N., Kozak, A. M. ve Kozak, M. (2012). Genel Turizm; Ilkeler-Kavramlar. Ankara: Detay Yayıncilik.

Leiper, N. (1995). Tourism Management. Melbourne: RMIT Pres.

Lickorish, L. J. and Jenkins, C. L. (1997). An Introduction to Tourism. Oxford: Routledge.

MacCannell, D. (1976). The Tourist: A New Theory of the Leisure Class. London: Macmillan.

McIntosh, R. and Gupta, S. (1980). Tourism: Principles, Practices, Philosophies. USA: Grid Publishing. 
Metin, Ş. ve Aral, N. (2012). Dört-Yedi Yaş Çocuklarının Resim Gelişim Özelliklerinin İncelenmesi. Ankara Sağlık Bilimleri Dergisi, 1(2): 55-69.

Mill, R. C. and Morrison, A. M. (1985). The Tourism System: An Introductory. New Jersey: Prentice Hall Inc.

Nickerson, N. and Jurowski, C. (2001). The Influence of Children on Vacation Travel Patterns, Journal of Vacation Marketing, 7: 19-30

Olalı, H. ve Timur, A. (1988). Turizm Ekonomisi. İzmir: Ofis Ofset Matbaacılık.

Özönder Aydın, U. (2017). Okul Öncesi Resim Eğitiminde Çocuğun Çizgisel Gelişimi (2-7 Yaş). Kastamonu Eğitim Dergisi, 25 (6): 2215-2228.

Pearce, P. L. (1982). The Social Psychology of Tourist Behaviour. Sydney: Pergamon.

Rhoden, S., Hunter-Jones, P. and Miller, A. (2016). Tourism Experiences Through the Eyes of a Child, Annals of Leisure Research, 19(4): 424-443.

Semiz, B. ve Sözer Çapan, A. (2019). Okul Öncesi Dönem Çocuklarının Ev, Ağaç ve İnsan Çizimlerindeki Doğa ile İlgili Figürlerin İncelenmesi. 14. Ulusal Okul Öncesi Öğretmenliği Öğrenci Kongresi, İstanbul.

Stolley, R. (2012). Working With Children and Their Drawings. Doctoral Dissertation. University of Wisconsin.

Şener, G. (2018). Şema Öncesi Dönem Çocuklarının (4-7 Yaş) Okul Temalı Resimlerine İlişkin Yorumlamalar. Muğla Sıtkı Koçman Üniversitesi Ĕ̆itim Fakültesi Dergisi, 5(2): 31-42.

Şimşek-İşliyen, F. ve İşliyen, M. (2015). Çocukların Medya Algısının Resimler Üzerinden Analizi. Global Media Journal TR Edition, 5(10): 271-287.

Tanrısever, C., Koç, E. D. ve Anvarova, Z. (2018). Turizm Bilincinin Kazandırılmasında Okul Öncesi Ĕgitimin Rolü, Turizm Araştırmaları Dergisi, (1): 33-46.

Toskay, T. (1983). Turizm Olayına Genel Yaklaşım. İstanbul: Der Yayınları.

Türkcan, B. (2013). Çocuk Resimlerinin Analizinde Göstergebilimsel Bir Yaklaşım. Kuram ve Uygulamada Ĕ̆itim Bilimleri, 13(1): 585-607.

Ülger, S. (1993). Genel Turizm Bilgisi. Antalya: Akdeniz Üniversitesi Basımevi.

Wu, M., Wall, G., Zu, Y. and Ying, T. (2019). Chinese Children's Family Tourism Experiences. Tourism Management Perspectives, 29: 166-175.

Yaman Bozdemir, K. (2020). Erken Çocukluk Dönemi Resim Eğitiminde Çocukların Gelişim Süreçleri ve Aile Tutumları. İstanbul Aydın Üniversitesi Güzel Sanatlar Fakültesi Dergisi, 6 (11): 1932. 
Yavuzer, H. (2016). Resimleriyle Çocuk. İstanbul: Remzi Kitabevi.

Yang, M. J. H, Yang, E. L. C. and Khoo-Lattimore, C. (2020) Host-Children of Tourism Destinations: Systematic Quantitative Literature Review. Tourism Recreation Research, 45(2): 231246.

Yıldırım-Doğru, S.S., Turcan, A. İ., Arslan, E. ve Doğru, S. (2006). Çocukların Resimlerindeki Aileyi Tanılama Durumlarının Değerlendirilmesi. Selçuk Üniversitesi Sosyal Bilimler Enstitüsü Dergisi, (15): 223-235.

Yukay-Yüksel, M., Canel, N., Mutlu, N., Yılmaz, S. ve Çap, E. (2015). Okul Öncesi Çağdaki Çocukların İyi ve Kötü Kavram Algılarının Resim Analizi Yöntemiyle İncelenmesi. Değerler Eğitimi Dergisi, 13 (29): 271-303.

Yurtal, F. ve Artut, K. (2008). Çocukların Şiddeti Algılama Biçimlerinin Çizdikleri Resimlerine Yansımaları. Çocuk ve Gençlik Ruh Sağhı̆̆ı Dergisi, 15(3): 149-155.

Yüce, A. (2016). Çocuk Resminde Nesnenin Temsili. İdil Sanat ve Dil Dergisi, 5(21): 313-322.

Zlateva, A. (2019). How to Read Childrens' Drawings. Resilience and Health by the Centre for Resilience and Socio-Emotional Health. Malta: University of Malta. 